\title{
Use of a lacZ Gene Fusion to Determine the Dependence Pattern of Sporulation Operon spoIIIC in spo Mutants of Bacillus subtilis: a Branched Pathway of Expression of Sporulation Operons
}

\author{
By S. M. TURNER, J. ERRINGTON AND J. MANDELSTAM* \\ Microbiology Unit, Department of Biochemistry, University of Oxford, South Parks Road, \\ Oxford OXI $3 Q U, U K$
}

(Received 23 May 1986; revised 23 June 1986)

\begin{abstract}
The sporulation gene spoIIIC from Bacillus subtilis was fused to the lacZ gene from Escherichia coli, so that the transcription of the lac $Z$ gene was under the control of the spoIIIC promoter. Production of $\beta$-galactosidase, under conditions of sporulation, was then used as an indicator to study the expression of spoIIIC in relation to other sporulation loci. Expression of spoIIIC, which occurred only in the mother cell compartment, was prevented by mutations in all of the stage 0 and stage II loci, and also by spoIIID, spoIVA and spoIVB mutations. By contrast, the last three operons are not needed for expression of spoVA, which has previously been shown to be sporespecific. In consequence, a branched pathway of gene expression is proposed. One branch leads to expression of spoVA within the spore compartment, the other to expression of spoIIIC in the mother cell.
\end{abstract}

\section{INTRODUCTION}

It has been suggested that the expression of sporulation operons could occur in a linear dependent sequence, i.e. a sequence in which each step is dependent on the one before (Mandelstam, 1976). The possibility has also been considered that there might be parallel or branched pathways, but there has been no firm evidence for such an assumption (Coote \& Mandelstam, 1973; Piggot \& Coote, 1976), although Lencastre \& Piggot (1979) obtained indirect genetic evidence that some operons might be expressed specifically in one of the cell compartments (i.e. spore or mother cell).

Investigation of the sequential expression of various sporulation operons has been greatly facilitated by the construction of genetic fusions to the Escherichia coli lac Z gene (e.g. Zuber \& Losick, 1983; Stephens et al., 1984). The method has been used to study the control of the sporulation operons spoIID (Clarke et al., 1986), spoIIA (Errington \& Mandelstam, 1986a) and spoVA (Errington \& Mandelstam, 1986b), and their dependence on the previous expression of other sporulation operons, i.e. their dependence patterns.

This paper describes a study of the expression of the spoIIIC locus of Bacillus subtilis using a lac Z fusion.

\section{METHODS}

Bacterial strains, phages and plasmids. These are listed in Table 1.

Induction of sporulation. Bacteria were grown at $37^{\circ} \mathrm{C}$ in casein hydrolysate $(\mathrm{CH})$ medium, supplemented with the appropriate growth requirements, until mid-exponential phase, and then induced to sporulate in resuspension medium as described by Sterlini \& Mandelstam (1969). The time zero for induction of sporulation and the hourly intervals thereafter are referred to as $t_{0}, t_{1}$, etc.

Phage $\phi 105$ methods. Methods for the preparation of phage lysates and for infection by, and assay of, phage $\phi 105$ and its derivatives are described elsewhere (Jenkinson \& Mandelstam, 1983; Errington, 1984; Errington, \& Mandelstam, 1986a). 


\section{Table 1. Plasmids, bacteriophage and bacterial strains}

Relevant characteristics

\begin{tabular}{|c|c|}
\hline $\begin{array}{l}\text { Plasmids } \\
\text { pMR6 } \\
\text { pSGMU32 }\end{array}$ & $\begin{array}{l}\text { bla }^{+} \mathrm{cat}^{+} \mathrm{spoIIIC}^{+} \\
\mathrm{bla}^{+} \mathrm{lacZ}^{+} \mathrm{cat}^{+}\end{array}$ \\
\hline \multicolumn{2}{|l|}{ Phage } \\
\hline$\phi 105 \mathrm{DI}: 1 \mathrm{t}$ & $\begin{array}{l}4.0 \mathrm{kbp} \text { deletion of } \\
\text { non-essential DNA }\end{array}$ \\
\hline$\phi 105 \mathrm{~J} 42$ & $\begin{array}{l}\text { Tail-less spoIIIC } C^{+} \text {transducing } \\
\text { phage }\end{array}$ \\
\hline$\phi 105 \mathrm{~J} 43$ & $\begin{array}{l}\text { Tail-less phage carrying } \\
\text { spoIIIC : : lacZ fusion }\end{array}$ \\
\hline$\phi 105 \mathrm{~J} 20$ & $\begin{array}{l}\text { Tail-less phage carrying } \\
\text { spoVA : : lac } Z \text { gene fusion }\end{array}$ \\
\hline \multicolumn{2}{|c|}{ Strain of $E$. coli } \\
\hline JM103 & $\begin{array}{c}\Delta(\text { lac-pro }) \text { thi strA supE end } A \text { sbcB15 } \\
\text { hsdR4 } \mathrm{F}^{\prime} \text { traD } 36 \text { proAB lacl }{ }^{q} Z \Delta M 15\end{array}$ \\
\hline \multicolumn{2}{|c|}{ Strains of $B$. subtilis $\dagger$} \\
\hline 168 & $\mathrm{Spo}^{+} \operatorname{trp} C 2$ \\
\hline SG38 & $\mathrm{Spo}^{+} \operatorname{trp} C 2$ \\
\hline 23.1 & spolVC23 trpC2 rpoB2 \\
\hline 513.2 & spoVIA513 metBS \\
\hline 590 & spoIIIF 590 lys-1 \\
\hline 610.1 & spoVIC610 pheA12 \\
\hline 618 & trpC2 spoIIIC : :lacZ-cat \\
\hline
\end{tabular}

Source or reference

Gift from A. L. Sonenshein

Errington (1986)

Flock (1977)

\} This paper

Errington \& Mandelstam (1986b)

Messing et al. (1981)

\author{
Laboratory stock \\ Errington \& Mandelstam (1986a) \\ E31, Waites et al. (1970)* \\ Jenkinson (1981) \\ Lamont \& Mandelstam (1984) \\ James \& Mandelstam (1985) \\ This paper
}

* E31 is the previous designation of this strain.

+ All the other Spo ${ }^{-}$strains that were used, viz. 1.5, 2.12, 17, 25.7, 36, 43.6, 48.7, 55.3, 65, 67, 85.3, 88.7, $89.10,91,92.5,93.2,131.5,134,141,156,165.3,221.1,224.1,298.4,484.2,485,486,488.8,496.1,497.1,498$, $516,517,520.3,522.2,562.5,612.2$, are listed in Table 1 of Errington \& Mandelstam (1986a).

Buffers. Ligation buffer was $50 \mathrm{~mm}$-Tris/ $\mathrm{HCl} \mathrm{pH} 7 \cdot 4,10 \mathrm{~mm}-\mathrm{MgCl}_{2}, 10 \mathrm{~mm}$-DTT, $1.0 \mathrm{~mm}$-spermidine, $1.0 \mathrm{~mm}$ ATP, bovine serum albumin $\left(0 \cdot 1 \mathrm{mg} \mathrm{ml}^{-1}\right)$. TE buffer was $10 \mathrm{~mm}$-Tris/HCl, 1 mM-EDTA (pH 7.5). Klenow reaction buffer (final concentration) was $10 \mathrm{mM}-\mathrm{Tris} / \mathrm{HCl} \mathrm{pH} 8 \cdot 0,5 \mathrm{mM}-\mathrm{MgCl}_{2}$.

Restriction endonuclease digestions. Restriction enzymes were obtained from Amersham or BRL and were used as recommended by the suppliers.

Transformation of $B$. subtilis. Recipient cells of $B$. subtilis were made competent and transformed by the method of Anagnostopoulos \& Spizizen (1961) as modified by Jenkinson (1983).

Transformations in E. coli. The transformation of plasmid pMR6, isolated and kindly provided by $\mathbf{M}$. Rosenkrantz and A. L. Sonenshein (Tufts University Medical School, Boston, Mass., USA), into E. coli strain JM103 was done as described in the Amersham booklet M13 Cloning and Sequencing Handbook.

Preparation of DNA. Plasmid DNA was extracted from $E$. coli by the alkaline lysis method of Birnboim \& Doly (1979) as described by Maniatis et al. (1982). Chromosomal DNA from B. subtilis was prepared by the method of Ward \& Zahler (1973). Phage DNA was prepared as described by Errington (1984).

When necessary, cohesive ends resulting from digestion with restriction endonucleases were blunted by treatment with the Klenow fragment of DNA polymerase I (Amersham). The DNA, Klenow reaction buffer, $4 \mu \mathrm{l}$ of a solution containing all four deoxyribonucleotide triphosphates (each at $0.5 \mathrm{mM}$ ) and 1 unit of Klenow fragment were suspended in a final volume of $30 \mu \mathrm{l}$ and incubated at room temperature for $10 \mathrm{~min}$. The mixture was then heated to $70{ }^{\circ} \mathrm{C}$ for $10 \mathrm{~min}$ to inactivate the enzyme.

Construction of a spoIIIC : : lacZ transcriptional gene fusion. Plasmid pSG32 (Errington, 1986) is a derivative of plasmid pUC18 (Norrander et al., 1983) containing a $4.8 \mathrm{kbp} \mathrm{BamHI}$ insert that includes two genes: a hybrid gene consisting of the amino-terminal-coding region and the ribosome binding site from the spoIIAA gene of $B$. subtilis fused in frame to the $l a c Z$ gene of $E$. coli, and a selectable chloramphenicol resistance gene, cat. This lac Z-cat cartridge was constructed in such a way that the $l a c Z$ gene can be expressed only if the cartridge is fused to the promoter of an adjacent gene, while the chloramphenicol gene is transcribed constitutively from its own promoter. Plasmid pSG32 $(4 \mu \mathrm{g})$ was digested first with $S m a I$ and then with HindIII to excise the lacZ-cat cartridge. 


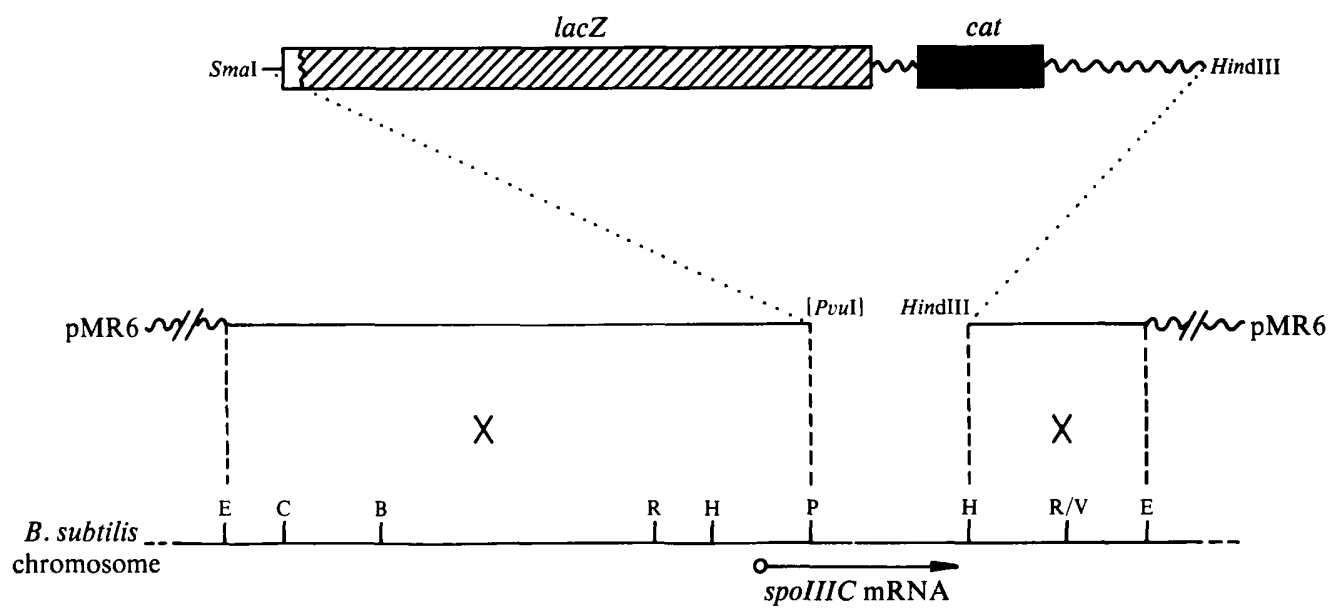

$1 \mathrm{kbp}$

Fig. 1. Construction of a spoIIIC : :lacZ fusion. The lowest part of the figure shows a restriction map of the spoIIIC region of the chromosome, incorporating sites for the following enzymes: $B g I I I$ (B), ClaI (C), EcoRI (E), EcoRV (R), HindIII (H), PvuI (P) and PvuII (V). Below, the horizontal arrow indicates the direction and approximate location of spoIIIC transcription (A. L. Sonenshein, personal communication). The upper part of the figure shows the molecules which were involved in the construction of the spoIIIC : : lac Z transcriptional fusion. The hatched box represents the lac $Z$ gene, which is actually a hybrid gene consisting of part of the upstream non-translated region (including ribosome binding site) and the first 23 codons from the spoIIAA gene fused, in frame, to all but the first 8 codons of $l a c Z$ (Errington, 1986). Unlike the wild-type lacZ gene (Donnelly \& Sonenshein, 1984), this hybrid gene is efficiently translated in $B$. subtilis (Errington, 1986; Errington \& Mandelstam, 1986a). The filled box represents a selectable chloramphenicol resistance determinant, cat. This 'lac-cat cartridge' was released from plasmid pSGMU32 (not shown) by digestion with SmaI and HindIII and was ligated to fragments of DNA having homology to the spoIIIC region of the B. subtilis chromosome, which were obtained by digestion of plasmid pMR6. The latter fragments, which are shown as thin straight lines, have been aligned over their respective regions of homology with the chromosome. DNA segments of plasmid origin are shown as wavy lines. As indicated by the dotted lines, the SmaI end of the lac-cat cartridge could ligate only to a pMR6 fragment possessing a PvuI end (as indicated by the square brackets, these ends were blunted before ligation). Similarly, the HindIII end of the cartridge could ligate only to other HindIII ends in the mixture. After transformation of a $B$. subtilis recipient strain, only an arrangement of the type shown for ligation of the participating molecules, and a crossover event in both regions of homology (delimited by broken lines), could give rise to stable chloramphenicol-resistant clones (Niaudet et al., 1985; Errington, 1986). The result of the recombination event shown would be the replacement of a PvuI-HindIII fragment of the recipient chromosome by the lac-cat cartridge, which would lie in an orientation such that lacZ expression could occur from the spoIIIC promoter. Also possible, but not shown in this figure, would be transformants in which the lac-cat cartridge was inserted in the reverse orientation, in place of the smaller HindIII-PvuI fragment.

M. Rosenkrantz and A. L. Sonenshein kindly provided us with plasmid pMR6, which was thought to contain the intact spoIIIC locus as a $4.7 \mathrm{kbp}$ EcoRI insertion in plasmid pBR325. The lower part of Fig. 1 shows a restriction map of the insert in plasmid pMR6 and the tentative location and orientation of the spoIIIC mRNA transcript (W. Finston, S. Rong \& A. L. Sonenshein, personal communication).

Plasmid pMR6 $(5 \mu \mathrm{g})$ was digested with PvuI, and the resultant cohesive ends blunted with Klenow fragment and then digested with $H$ indIII. A portion $(2 \mu \mathrm{g})$ of the lac $Z$-cat cartridge from pSG32 was ligated to $2.5 \mu \mathrm{g}$ plasmid pMR6 DNA, pretreated as described above. The ligation mixture was incubated at $4{ }^{\circ} \mathrm{C}$ for $16 \mathrm{~h}$ and then used to transform competent cells of $B$. subtilis strain CU267. Transformed bacteria were plated on nutrient agar (Oxoid) containing chloramphenicol $\left(5 \mu \mathrm{g} \mathrm{ml}^{-1}\right)$ and 4-methylumbelliferyl- $\beta$-D-galactoside (MUG; $50 \mu \mathrm{g} \mathrm{ml}^{-1}$ ), which yields a fluorescent hydrolysis product with $\beta$-galactosidase (Youngman et al., 1985). After overnight incubation at $37^{\circ} \mathrm{C}$ colonies were inspected for fluorescence over an ultra-violet transilluminator.

Fluorescent colonies were subcultured on nutrient agar to check that these isolates were $\mathrm{Spo}^{-}$and stable.

Measurement of $\beta$-galactosidase activity. Samples $(0.5 \mathrm{ml})$ from sporulating cultures were assayed for $\beta$ galactosidase activity using a method based on hydrolysis of MUG (Errington \& Mandelstam, 1986a). One unit of $\beta$-galactosidase catalyses the hydrolysis of $1 \mathrm{nmol} \mathrm{MUG} \mathrm{min}^{-1}$ in the standard assay. 
Measurement of alkaline phosphatase activity. Samples of sporulating cell cultures (1.5 ml) were assayed for alkaline phosphatase activity as described by Errington \& Mandelstam (1983). One unit of alkaline phosphatase hydrolyses $1 \mathrm{nmol}$ of substrate, $p$-nitrophenyl phosphate, in $15 \mathrm{~min}$ at $30^{\circ} \mathrm{C}$.

$\beta$-Galactosidase distribution in mother cell and spore fractions. Samples from sporulating cultures at $t_{5.5}$ were divided into 'spore' (pellet) and 'mother cell' (supernatant) fractions after passage through a French pressure cell as described previously (Errington \& Mandelstam, 1986 ). The resultant $0.5 \mathrm{ml}$ samples were treated with or without germinant as described previously except that the final volume of the treated samples was made to $600 \mu l$ rather than to $1 \mathrm{ml}$ (i.e. a more concentrated solution of germinants was added).

\section{RESULTS}

\section{Construction of a spoIIIC : : lacZ transcriptional fusion}

To construct a spoIIIC: :lacZ transcriptional fusion, we first digested plasmid pMR6 separately with HindIII and with PvuI, and then ligated the resulting fragments to a lac-cat cartridge (Errington, 1986) in such a way as to provide the cartridge with flanking regions that were homologous to the $B$. subtilis chromosome in the spoIIIC region; transformation of the product of the ligation mixture into $B$. subtilis would then lead to insertion of the cartridge into spoIIIC (Fig. 1). [The lac-cat cartridge was excised from plasmid pSGMU32 by digestion with HindIII and SmaI. Ligation of PvuI with SmaI ends was made possible by 'filling in' the PvuI cohesive ends (see Methods).] The ligation mixture was transformed into the $B$. subtilis wild-type strain 168 with selection for chloramphenicol resistance. This procedure selected for integration of the lac-cat cartridge in place of one or other of the HindIII-PvuI fragments in the spoIIIC region of-the recipient chromosome (Niaudet et al., 1985; Errington, 1986). As expected, of about 100 transformants, almost all were stably $\mathrm{Spo}^{-}$as a result of the chromosomal disruption, and about $15 \%$ of these produced $\beta$-galactosidase as judged by fluorescence on plates containing the indicator MUG (Youngman et al., 1985), presumably as a result of transcription of the lac Z gene from the spoIIIC promoter. The non-fluorescent $\mathrm{Spo}^{-}$colonies presumably contained an integrated lac-cat cartridge in the wrong orientation (i.e. the reverse of that shown in Fig. 1). Differences in the sizes of the flanking homologous fragments of DNA probably account for the observed inequality of recovery of the alternative classes.

The $4.7 \mathrm{kbp} E c o$ RI fragment of $B$. subtilis DNA in plasmid pMR6 was thought to contain the intact spoIIIC transcription unit (see above). To test for complementation of mutation spoIIIC496 (previously called 94U; Ionesco et al., 1970) and of the new spoIIIC : :lacZ-cat mutant (designated strain 618), this fragment was subcloned into phage $\phi 105 \mathrm{DI}:: 1 \mathrm{t}$ by prophage transformation (see Methods). A spoIIIC ${ }^{+}$transducing phage was isolated (designated $\phi 105 \mathrm{~J} 42)$ and its restriction map is shown in Fig. 2. In this phage, EcoRI fragments E $(5 \cdot 3 \mathrm{kbp})$ and I $(0.48 \mathrm{kbp})$ of $\phi 105 \mathrm{DI}: 1 \mathrm{t}$ have been replaced by a new fragment of the expected size, $4.7 \mathrm{kbp}$. As with other phages having a deletion of EcoRI fragments in the same region, $\phi 105 \mathrm{~J} 42$ is tail-less and can transduce only in the presence of wild-type helper phage (Iijima et al., 1980; Jenkinson \& Mandelstam, 1983). Transduction of strains 496.1, carrying the original mutation, spoIIIC496, and 618, containing the new chromosomal disruption, in both cases led to the production of spores resistant to chloroform vapour.

\section{Transfer of the chromosomal spoIIIC : : lacZ gene fusion to phage $\phi 105 \mathrm{~J} 42$}

As described for the analysis of lac $Z$ gene fusions to both spoIIA and spoVA in an accompanying paper (Errington, 1986), analysis of expression is facilitated by transfer of the gene fusion to phage $\phi 105$, which can be used to lysogenize strains of differing genotype. To bring about this transfer, chromosomal DNA from strain 618 was used to transform a derivative of strain 496.1 , which was lysogenic for phage $\phi 105 \mathrm{~J} 42$ and hence phenotypically $\mathrm{Spo}^{+}$. Insertion of the transcriptional fusion into the prophage by a double-crossover recombination event would be expected to give rise to $\mathrm{Spo}^{-}$transformants, whereas integration at the chromosomal spoIIIC locus would give transformants that remained $\mathrm{Spo}^{+}$(Errington, 1986). Unfortunately, it was not easy to distinguish the difference between $\mathrm{Spo}^{+}$and $\mathrm{Spo}^{-}$ transformants on plates containing chloramphenicol, so all the chloramphenicol-resistant transformants were pooled and a phage lysate was prepared, which was then tested for 


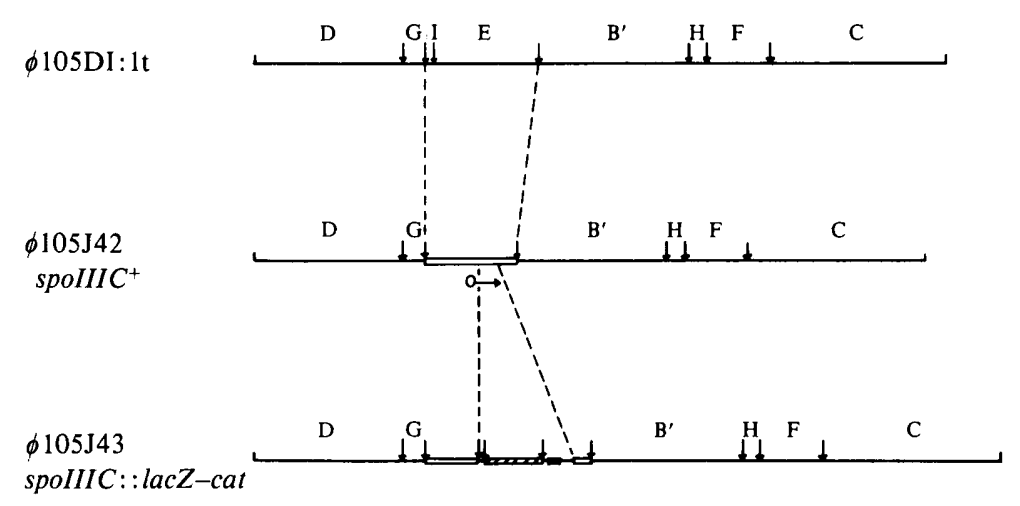

\begin{abstract}
$5 \mathrm{kbp}$
Fig. 2. EcoRI restriction maps of phages $\phi 105 \mathrm{DI}: 1 \mathrm{t}, \phi 105 \mathrm{~J} 42$ and $\phi 105 \mathrm{~J} 43$. The vertical arrows indicate the locations of $E c o R I$ restriction sites. One letter designations for the fragments of phage origin are given (Bugaichuk et al., 1984). Fragment $B^{\prime}$ was derived from fragment B of wild-type $\phi 105$ by deletion of $4 \mathrm{kbp}$ of non-essential DNA (Flock, 1977). The open box represents chromosomal DNA from the spoIIIC region, and the direction and approximate extent of spoIIIC transcription (A. L. Sonenshein, personal communication) is indicated by a horizontal arrow. The hatched box and the filled box represent the $l a c Z$ and chloramphenicol-resistance genes respectively. Broken lines indicate the boundaries of the gene replacement events that occurred during the construction of $\phi 105 \mathrm{~J} 42$ and $\phi 105 \mathrm{~J} 43$ (see text).
\end{abstract}

transduction of chloramphenicol-resistance to recipient strain CU267. Phage DNA from a purified transductant was subjected to restriction mapping and the deduced structure of this phage, designated $\phi 105 \mathrm{~J} 43$, is shown in Fig. 2 . The new phage had a structure similar to that of $\phi 105 \mathrm{~J} 42$ except that the $0.8 \mathrm{kbp} P v u \mathrm{I}-H i n d I I I$ fragment of DNA from the spoIIIC region was replaced, as expected, by a $4.8 \mathrm{kbp}$ DNA segment corresponding to the lac $Z$-cat cartridge. The orientation of the cartridge was such that transcription of the lac $Z$ gene was in the proposed direction for spoIIIC expression (W. Finston, S. Rong \& A. L. Sonenshein, personal communication). In plate tests, all of the chloramphenicol-resistant transductants in this and in subsequent experiments with $\phi 105 \mathrm{~J} 43$ in appropriate recipient strains produced colonies that showed $\beta$-galactosidase activity.

\title{
Production of $\beta$-galactosidase from the spoIIIC : :lacZ fusion under sporulation conditions
}

$\mathrm{A} \mathrm{Spo}^{+}$strain of B. subtilis, SG38, was infected with $\phi 105 \mathrm{~J} 43$ and used as a positive control for all sporulation experiments. The activity of $\beta$-galactosidase was measured in this strain at $t_{0}$, and at intervals thereafter. The results of a typical time course are shown in Fig. 3. $\beta$-Galactosidase began to be produced at approximately $t_{2 \cdot 5}$ and reached a maximum at $t_{5}$. A similar pattern was observed when strain 618 (the strain carrying the spoIIIC::lacZ gene fusion on the chromosome) was transferred to sporulation medium. This was also found with all the sporulation mutants infected with $\phi 105 \mathrm{~J} 43$ that did not prevent expression of the spoIIIC : : lac Z gene fusion (see below), with the exception of strains harbouring mutations spoIIIF590 and spoVIC610. In such strains, expression of $\beta$-galactosidase was delayed by $1 \mathrm{~h}$ and it continued to increase throughout the experiment (Fig. 3). The production of alkaline phosphatase, a biochemical marker event which normally occurs at about $t_{1}$, was also delayed by $1 \mathrm{~h}$ in these strains as was the occurrence of later events.

Although $B$. subtilis does not grow on lactose, it has a $\beta$-galactosidase-like activity that gives rise to a background of fluorescence under standard assay conditions (see Errington \& Mandelstam, 1986a). The results for $B$. subtilis strain 168, the $\mathrm{Spo}^{+}$wild-type carrying no lac $Z$ fusion, are therefore included in Fig. 3. The background activity was low and there was no difficulty in distinguishing strains that produced $\beta$-galactosidase from those that did not. 


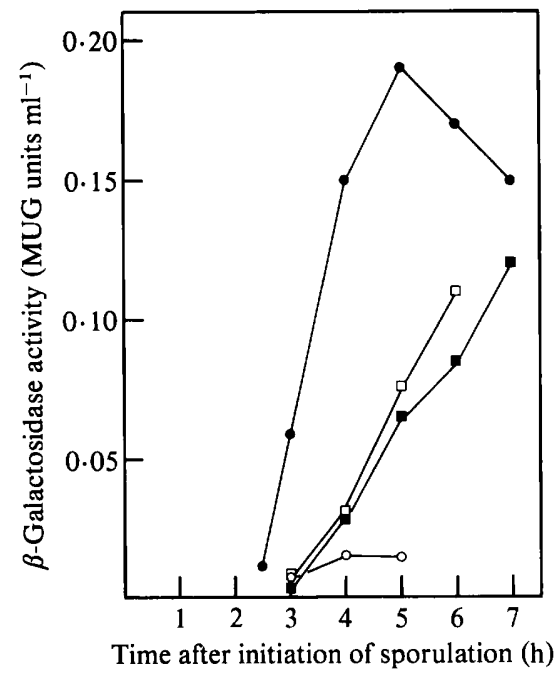

Fig. 3. Measurement of $\beta$-galactosidase activity in sporulating cells of strain 168 (Spo ${ }^{+}$, no lac $Z$ fusion, $O)$, and of the following strains lysogenic for $\phi 105 \mathrm{~J} 43$ (spoIIIC::lacZ): SG38 (Spo ${ }^{+}$), 610.1 (spoVIC610, $\square)$ and 590 (spoIIIF590,

\section{Table 2. Effect of various sporulation mutations on the expression of spoIIIC}

The spoIIIC : : lacZ gene fusion was transferred to each of the sporulation mutants by infection with phage $\phi 105 \mathrm{~J} 43$ and subsequent selection for chloramphenicol resistance. Cells were induced to sporulate and samples were taken at $1 \mathrm{~h}$ or $0.5 \mathrm{~h}$ intervals, for $\beta$-galactosidase assay. Each strain was tested for $\beta$-galactosidase production on at least two separate occasions. + , Activity reaching $55 \%$ or more of wild-type activity; $+^{*}$, activity reaching $55 \%$ or more of wild-type activity but delayed by about $1 \mathrm{~h} ;-$, the rapid increase in activity observed at about $t_{2 \cdot 5}$ in cultures giving positive results was absent, and the total activity was always less than $30 \%$ of that seen in the wild-type.

\begin{tabular}{cccccccc} 
Mutated & \multicolumn{7}{c}{$\beta$-Galactosidase activity } \\
\cline { 2 - 7 } locus & $0-I$ & $I I$ & $I I I$ & $I V$ & $V$ & $V I$ & Ger \\
$A$ & - & - & + & - & + & + & \\
$B$ & - & - & + & - & + & + & \\
$C$ & & & + & + & + & $+^{*}$ & \\
$D$ & - & - & - & + & + & & + \\
$E$ & - & - & + & + & + & & + \\
$F$ & - & & $+*$ & + & + & & \\
$G$ & - & - & & & & & \\
$H$ & - & & & & + & & \\
$J$ & - & & & & + & & \\
$K$ & - & & & & & &
\end{tabular}

Effect of various sporulation mutations on the expression of spoIIIC : : lacZ

Each of the sporulation mutant strains listed in Table 1 was infected with $\phi 105 \mathrm{~J} 43$, a phage carrying the spoIIIC : :lac Z fusion. Although the spoIIIC gene on this phage was disrupted by the lac-cat insertion, each sporulation mutant (except strain 496.1) carried a functional copy of spoIIIC in its chromosome. The effect of each spo mutation on the expression of spoIIIC was determined by measurement of $\beta$-galactosidase at intervals after the induction of sporulation (Table 2). All of the mutations that blocked sporulation at stage 0 and at stage II also blocked expression of spoIIIC, whereas those affecting stage V or stage VI, and a gerE mutation, did not. Mutations in spoVIC and spoIIIF caused a reproducible delay in its expression of about $1 \mathrm{~h}$ (see above). Mutations in spoIIID, spoIVA and spoIVB blocked expression of the spoIIIC gene, but those in the other stage III and stage IV loci did not. 
Table 3. Location of $\beta$-galactosidase activity in sporulating cells of strain SG38 ( $\phi 105 \mathrm{J43}$ )

Strain SG38 ( $\phi 105 \mathrm{~J} 43)$ was induced to sporulate and at $t_{5 \cdot 5}$ the cells were harvested. Various fractions were assayed for $\beta$-galactosidase after incubation with or without germinants (see Methods).

\begin{tabular}{lcc}
\multicolumn{1}{c}{ Sample } & 0.24 & Germinated \\
\cline { 2 - 3 } & 0.22 & 0.22 \\
Whole culture & & 0.22 \\
Whole culture after cell breakage & 0.22 & 0.22 \\
(French pressure cell) & 0.019 & 0.022 \\
'Mother cell fraction' (supernatant) & 'Spore fraction' (pellet)
\end{tabular}

\footnotetext{
* Cell samples from $25 \mathrm{ml}$ of sporulating culture were resuspended in $5 \mathrm{ml}$ of sodium phosphate buffer. All values given are for these concentrated suspensions and should be divided by five for direct comparison with other values from $\beta$-galactosidase assays.
}

\section{Location of $\beta$-galactosidase activity in differentiating sporulating cells}

We have previously shown (Errington \& Mandelstam, 1986b) that expression of the spoVA operon occurs predominantly, perhaps exclusively, in the spore compartment. To determine in which of the cell compartments spoIIIC expression occurs, we fractionated the differentiating cells (see Methods) and measured $\beta$-galactosidase activity in the spore and mother-cell fractions.

Derivatives of strain SG38 ( $\mathrm{Spo}^{+}$) lysogenic for phages $\phi 105 \mathrm{~J} 20$ (spoVAA : :lacZ) or $\phi 105 \mathrm{~J} 43$ (spoIIIC : :lacZ) were induced to sporulate, and at $t_{5 \cdot 5}$ the cells were harvested, divided into spore and mother-cell fractions, and assayed for $\beta$-galactosidase both before and after treatment with spore germinants (see Methods). The results (Table 3) clearly show that about $90 \%$ of the $\beta$ galactosidase produced from the spoIIIC::lacZ fusion gene resides in the mother-cell compartment. Germination had no effect on the observed activities. This contrasts with the observation that $\beta$-galactosidase activity expressed from a spoVAA::lacZ gene fusion was located predominantly in the spore compartment (Errington \& Mandelstam, 1986b). Full detection of this activity was only possible after treatment of the developing spores with germinants which sensitizes them to toluene and makes them permeable to the $\beta$-galactosidase substrate MUG (Errington \& Mandelstam, 1986b).

These results clearly support the notion that spoIIIC expression and spoVA expression occur in different cell compartments.

\section{DISCUSSION}

In the wild-type and in most of the mutants in which spoIIIC is expressed, the appearance of $\beta$ galactosidase indicates that the operon is 'turned on' at about $t_{2 \cdot 5}$ (Fig. 3). It is thus expressed at about the same time as spoVA (Errington \& Mandelstam, 1986 b), and about 1 to $1.5 \mathrm{~h}$ after spoIIA (Errington \& Mandelstam, 1986a) and spoIID (Clarke et al., 1986). The delayed expression of sporulation events in some mutants, e.g. spoIIIF and spoVIC, has been noted before (James \& Mandelstam, 1985; Errington \& Mandelstam, 1986a) and we have no explanation for it.

The expression of spoIIIC is dependent on the expression of all the known stage 0 operons and of all those that are known to control stage II (Table 2). Moreover, its expression is prevented by mutations in spoIIID, spoIVA and spoIVB. In Table 4 we have compared the dependence pattern of this operon with those of spoIIA, spoIID and spoVA, which have all been examined by the use of the appropriate lac $Z$ fusions. The contrast in the dependence patterns of spoIIIC and spoVA will be apparent. Both operons depend on the correct expression of all the operons involved in sporulation up to the end of stage II. The line of dependence then branches: expression of spoIIIC depends on spoIIID, spoIVA and spoIVB and is independent of spoIIIA, spoIIIB and spoIIIE (see below). The converse pattern of dependence holds for spoVA. 
Table 4. Summary of the effects of mutations at spo loci on expression of various spo: : lacZ fusions

Results for the four fusions are taken from the following sources: spoIIA : :lacZ, Errington \& Mandelstam (1986a); spoIID : :lacZ, Clarke et al. (1986); spoIIIC::lacZ, this paper; spoVA : :lacZ, Errington \& Mandelstam (1986b). - , Prevents expression of spo: :lacZ; +, allows expression of spo : : lacZ.

spo mutant background

$O A, O B, O D, O E, O F, O G, O H$

$I I A, I I E, I I G$

$I I B, I I D$

IIID, IVA, IVB

$I I I A, I I I B, I I I E$

All others tested

\begin{tabular}{|c|c|c|c|}
\hline \multicolumn{4}{|c|}{ Expression of fusion } \\
\hline spoIIA : :lacZ & spoIID : :lacZ & spoIIIC : :lacZ & spoVA: :lacZ \\
\hline- & - & - & - \\
\hline+ & - & - & - \\
\hline+ & + & - & - \\
\hline+ & + & - & + \\
\hline+ & + & + & - \\
\hline+ & + & + & + \\
\hline
\end{tabular}

If these conclusions are combined with those derived earlier from the dependence patterns of operons up to the end of stage II (Clarke et al., 1986), we arrive at the scheme shown below, in which operons whose order of expression is still undetermined are bracketed together (asterisks indicate that the dependence pattern was determined by the use of lac $Z$ fusions). The dependence of expression of spoIIG upon that of spoIIA was determined by immunological methods (Trempy et al., 1985). It thus appears that the single linear dependence sequence (see Mandelstam, 1976) holds until the end of stage II; it then becomes complicated by branching into two subsidiary sequences each of which also seems to exhibit dependence.

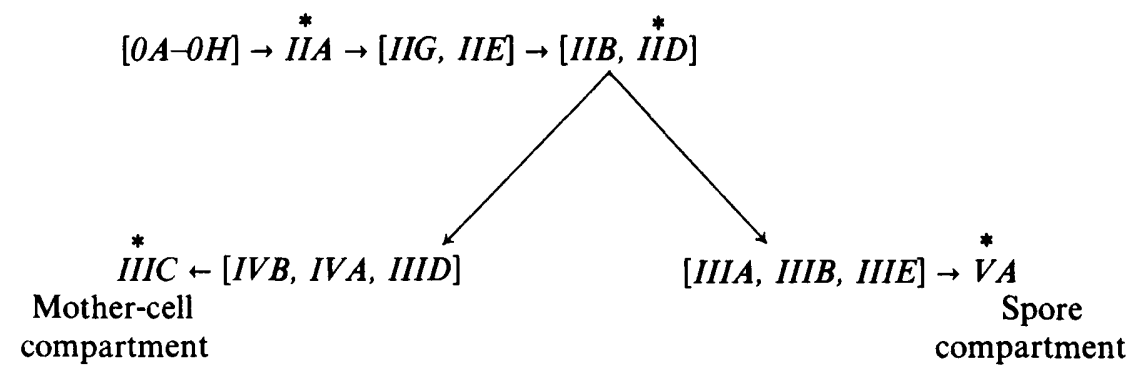

From the data in Table 3 it appears that spoIIIC is expressed in the mother cell. The small amount of $\beta$-galactosidase activity found in the spore fraction is not increased by treatment with germinants and this probably means that it is the result of adsorption of a small amount of the enzymes to the spores. This contrasts with the results found with spoVA which indicated that the operon is expressed only in the spore compartment: virtually all of the $\beta$-galactosidase activity was found in the spore fraction and its detection was greatly enhanced by treatment with germinants, presumably as a result of changes in spore permeability (Errington \& Mandelstam, $1986 b$ ). (Although the results obtained for the two different $s p o:: l a c Z$ fusions help to reinforce each other, we hope to confirm the cellular location of $\beta$-galactosidase in these strains by immuno-electron microscopy.) It is also consistent with the above scheme that mutations in the spoIIIC locus block late sporulation events such as spore coat protein synthesis that presumably occur specifically in the mother cell compartment (unpublished results based on electron microscopy). By contrast, mutations in the spoVA locus do not block such events (Errington \& Mandelstam, 1986b). We can therefore surmise that the alternative dependence pathways leading to expression of spoIIIC and spoVA reflect separate lines of gene expression that occur in the mother cell and spore compartments of the differentiating cell.

We are grateful to Dr A. L. Sonenshein and coworkers for providing us with plasmid pMR6 and with much useful unpublished data. Bridget Harris played an important part in the construction of phage $\phi 105 \mathrm{~J} 43$ and in characterizing the spoIIIC : :lacZ fusion. The work was supported by the Science and Engineering Research Council. J.E. is in receipt of a 1983 Research Fellowship of the Royal Society. 


\section{REFERENCES}

AnAGnostopoulos, C. \& Spizizen, J. (1961). Requirements for transformation in Bacillus subtilis. Journal of Bacteriology 81, 741-746.

BIRNBoIM, H. C. \& Doly, J. (1979). A rapid alkaline extraction procedure for screening recombinant plasmid DNA. Nucleic Acids Research 7, 1513-1523.

BugaichuK, U. D., Deadman, M., Errington, J. \& SAvva, D. (1984). Restriction enzyme analysis of Bacillus subtilis bacteriophage $\phi 105$ DNA. Journal of General Microbiology 130, 2165-2167.

Clarke, S., Lopez-Diaz, I. \& Mandelstam, J. (1986). Use of lacZ gene fusions to determine the dependence pattern of the sporulation gene spoIID in spo mutants of Bacillus subtilis. Journal of General Microbiology 132, 2987-2994.

Coote, J. G. \& Mandelstam, J. (1973). Use of constructed double mutants for determining the temporal order of expression of sporulation genes in Bacillus subtilis. Journal of Bacteriology 114, 12541263.

Donnelly, C. E. \& Sonenshein, A. L. (1984). Promoter probe plasmid for Bacillus subtilis. Journal of Bacteriology 157, 965-967.

ERRINGTON, J. (1984). Efficient Bacillus subtilis cloning system using bacteriophage vector $\phi 105 \mathrm{~J} 9$. Journal of General Microbiology 130, 2615-2628.

ERRINGTON, J. (1986). A general method for fusion of the Escherichia coli lacZ gene to chromosomal genes in Bacillus subtilis. Journal of General Microbiology 132, 2953-2966.

ERRINGton, J. \& MANDElstaM, J. (1983). Variety of sporulation phenotypes resulting from mutations in a single regulatory locus, spoIIA, in Bacillus subtilis. Journal of General Microbiology 129, 2091-2101.

ERRINGTON, J. \& MANDElSTAM, J. (1986a). Use of a lac $Z$ gene fusion to determine the dependence pattern of sporulation operon spoIIA in spo mutants of Bacillus subtilis. Journal of General Microbiology 132, 2967-2976.

Errington, J. \& Mandelstam, J. (1986b). Use of a lacZ gene fusion to determine the dependence pattern and the spore compartment expression of sporulation operon spoVA in spo mutants of Bacillus subtilis. Journal of General Microbiology 132, 29772985.

FLOCK, J.-I. (1977). Deletion mutants of temperate Bacillus subtilis bacteriophage $\phi 105$. Molecular and General Genetics 155, 241-247.

Iijima, T., Kawamura, F., Safto, H. \& IKeda, Y. (1980). A specialized transducing phage constructed from Bacillus subtilis phage $\phi 105$. Gene 9, 115-126.

IONESCO, H., Michel, J., CAMI, B. \& SChaEfFER, P. (1970). Genetics of sporulation in Bacillus subtilis Marburg. Journal of Applied Bacteriology 33, 13-24.

JAMES, W. \& MANDELSTAM, J. (1985). spoVIC, a new sporulation locus in Bacillus subtilis affecting spore coats, germination and the rate of sporulation. Journal of General Microbiology 131, 2409-2419.

JENKINSON, H. F. (1981). Germination and resistance defects in spores of a Bacillus subtilis mutant lacking a coat polypeptide. Journal of General Microbiology 127, 81-89.

JENKINSON, H. F. (1983). Altered arrangement of proteins in the spore coat of a germination mutant of Bacillus subtilis. Journal of General Microbiology 129, 1945-1958.
Jenkinson, H. F. \& MandelstaM, J. (1983). Cloning of the Bacillus subtilis lys and spoIIIB genes in phage $\phi 105$. Journal of General Microbiology 129, 22292240.

LAMONT, I. L. \& MANDELSTAM, J. (1984). Identification of a new sporulation locus, spoIIIF, in Bacillus subtilis. Journal of General Microbiology 130, 1253 1261.

LenCastre, H. DE \& Piggot, P. J. (1979). Identification of different sites of expression for spo loci by transformation of Bacillus subtilis. Journal of General Microbiology 114, 377-389.

MANDELSTAM, J. (1976). Bacterial sporulation: a problem in the biochemistry and genetics of a primitive developmental system. Proceedings of the Royal Society B193, 89-106.

Maniatis, T., Fritsch, E. F. \& SambrooK, J. (1982). Molecular Cloning: A Laboratory Manual. Cold Spring Harbor, NY: Cold Spring Harbor Laboratory.

Messing, J., Crea, R. \& Seeburg, P. H. (1981). A system for shotgun DNA sequencing. Nucleic Acids Research 9, 309-321.

MoIR, A. (1981). Germination properties of a spore coat-defective mutant of Bacillus subtilis. Journal of Bacteriology 146, 1106-1116.

NiAudet, B., JANNIERE, L. \& Ehrlich, S. D. (1985). Integration of linear, heterologous DNA molecules into the Bacillus subtilis chromosome: mechanism and use in induction of predictable rearrangements. Journal of Bacteriology 163, 111-120.

Norrander, J., Kempe, T. \& Messing, J. (1983). Improved M13 vectors using oligonucleotidedirected mutagenesis. Gene 26, 101-106.

Piggot, P. J. \& Coote, J. G. (1976). Genetic aspects of bacterial endospore formation. Bacteriological Reviews 40, 908-962.

StePhens, M. A., Lang, M., Sandman, K. \& Losick, R. (1984). A promoter whose utilization is temporally regulated during sporulation in Bacillus subtilis. Journal of Molecular Biology 176, 333-348.

Sterlini, J. M. \& MandelstaM, J. (1969). Commitment to sporulation in Bacillus subtilis and its relationship to development of actinomycin resistance. Biochemical Journal 113, 29-37.

Trempy, J. E., Morrison-Plummer, J. \& HaldenWANG, W. G. (1985). Synthesis of $\sigma^{29}$, an RNA polymerase specificity determinant, is a developmentally regulated event in Bacillus subtilis. Journal of Bacteriology 161, 340-346.

WaITES, W. M., KaY, D., DAWES, I. W., WOOD, D. A., WARREN, S. C. \& MANDELstaM, J. (1970). Sporulation in Bacillus subtilis. Correlation of biochemical events with morphological changes in asporogenous mutants. Biochemical Journal 118, 667-676.

WARD, J. B., JR \& ZAHLER, S. A. (1973). Genetic studies of leucine biosynthesis in Bacillus subtilis. Journal of Bacteriology 116, 719-726.

Youngman, P., Zuber, P., Perkins, J. B., Sandman, K., IGO, M. \& Losick, R. (1985). New ways to study developmental genes in spore-forming bacteria. Science 228, 285-291.

ZUBer, P. \& Losick, R. (1983). Use of a lacZ fusion to study the role of the spo0 genes of Bacillus subtilis in developmental regulation. Cell 35, 275-283. 